November 2016

\title{
A Historian's View of the International Freedom of Expression Framework
}

Antoon De Baets

University of Groningen

Follow this and additional works at: https://scholarworks.sjsu.edu/secrecyandsociety

Part of the History Commons, Law Commons, and the Social and Behavioral Sciences Commons

\section{Recommended Citation}

De Baets, Antoon. 2016. "A Historian's View of the International Freedom of Expression Framework." Secrecy and Society 1(1). https://doi.org/10.31979/2377-6188.2016.010108 https://scholarworks.sjsu.edu/secrecyandsociety/vol1/iss1/8

This Article is brought to you for free and open access by the School of Information at SJSU ScholarWorks. It has been accepted for inclusion in Secrecy and Society by an authorized administrator of SJSU ScholarWorks. For more information, please contact scholarworks@sjsu.edu.

\section{(c) (1)}

This work is licensed under a Creative Commons Attribution 4.0 License. 


\section{A Historian's View of the International Freedom of Expression Framework}

\section{Keywords}

freedom of expression, freedom of opinion, human rights, United Nations

\section{Cover Page Footnote}

This essay was first presented as a key-note speech entitled "Laws Governing the Free Expression of Historians in Democracies," at the international conference on "StateSponsored History" in Ghent, Belgium, on 25 November 2015. I thank Toby Mendel, director of the Centre for Law and Democracy (Canada), for his critical reading of a draft of this article. 


\section{A Historian's View of the International Freedom of Expression Framework}

\section{Antoon De Baets}

The international freedom of expression framework as established by the United Nations in recent decades has been the accumulated and sophisticated result of philosophical and legal thinking since the Enlightenment, if not earlier. The framework is an integral part of the international human rights system and it is shared almost worldwide, albeit with some regional variations. It is common inside legal circles, but less well-known outside of it. This is regrettable as the framework provides standards to discuss the merits of different law types and offers criteria to evaluate arguments in discussions about free expression, information and secrecy. Scholars outside the legal realm need to develop their own reading of it. Therefore, I shall approach it here, by way of illustration, from the particular angle of my own profession, history. It goes without saying that many history-related remarks are applicable, mutatis mutandis, to other scholarship as well. I provide only an outline of the framework, although many of its parts merit in-depth treatment. 


\section{The Standards}

The standards that regulate the universal right to freedom of opinion and expression on a global scale are written down in articles 19 and 20 of the International Covenant on Civil and Political Rights (ICCPR). The ICCPR is a formal elaboration of the 1948 Universal Declaration of Human Rights. It was approved by the United Nations in 1966 and as of June 2016 ratified by 168 states (representing $80 \%$ of the world population). ${ }^{1}$ Article 19.1 describes the formation of opinions, article 19.2 their expression, article 19.3 their restriction, and article 20 their prohibition.

Article 19 ICCPR:

1. Everyone shall have the right to hold opinions without interference.

2. Everyone shall have the right to freedom of expression; this right shall include freedom to seek, receive and impart information and ideas of all kinds, regardless of frontiers, either orally, in writing or in print, in the form of art, or through any other media of his choice.

3. The exercise of the rights provided for in paragraph 2 of this article carries with it special duties and responsibilities. It may therefore be subject to certain restrictions, but these shall only be such as are provided by law and are necessary:

(a) For respect of the rights or reputations of others;

\footnotetext{
${ }^{1}$ See http:// indicators.ohchr.org. Countries that have not yet ratified the International Covenant on Civil and Political Rights (ICCPR) include China, Cuba, Malaysia, Myanmar and Saudi Arabia.
} 
(b) For the protection of national security or of public order (ordre public), or of public health or morals.

Article 20 ICCPR

1. Any propaganda for war shall be prohibited by law.

2. Any advocacy of national, racial or religious hatred that constitutes incitement to discrimination, hostility or violence shall be prohibited by law.

If we are to interpret these two articles, we need the guidance of the Human Rights Committee, a United Nations body established in 1976 to supervise compliance with the ICCPR by the states parties (the ratifying states). One of the Committee's tasks is to issue authoritative interpretations of the various ICCPR articles. In 2011, it produced a General Comment on article 19 , which will be our main guide here. ${ }^{2}$ In introducing the freedoms of opinion and expression, the Committee recalled why they are so important for individuals, for society and for the state:

[They] are indispensable conditions for the full development of the person...They constitute the foundation stone for every free and democratic society... Freedom of expression is a necessary condition for the realization of the principles of transparency and accountability that are, in turn, essential for the promotion and protection of human rights. $^{3}$

\footnotetext{
${ }^{2}$ Human Rights Committee (HRC), General Comment 34 [on the freedoms of opinion and expression) (2011). The principal drafter of this General Comment was HRC member Michael O'Flaherty, professor at the National University of Ireland in Galway. General Comment 34 replaces General Comment 10 [on freedom of expression] (1983). See also General Comment 11 [on the prohibition of propaganda for war and inciting national, racial or religious hatred] (1983).

${ }^{3}$ HRC, General Comment 34, §§2-3.
} 
If we read these rationales with the eyes of the historian, we note that the idea of history is tacitly but completely immersed in them in two respects. First, everyone needs to somehow reflect on the past in order to achieve full personal development. Second, history as a craft, as long as it is done responsibly, helps foment a democratic society, among others because historical information can inform important political debates and therefore contribute to achieving government transparency and accountability. ${ }^{4}$

\section{Article 19.1: The Formation of Opinions}

Article 19.1 establishes the right to hold opinions. Two principles underpinning its logic are of utmost importance to historical writing. The first is the right to form and hold historical opinions (that is, interpretations of past events and moral judgments about the conduct of historical figures).

The Human Rights Committee observed:

Paragraph 1 of article 19 requires protection of the right to hold opinions without interference. This is a right to which the Covenant permits no exception or restriction ... All forms of opinion are protected, including opinions of a political, scientific, historic, moral or religious nature. ${ }^{5}$

This commentary emphasizes the absolute and non-derogable right to hold opinions, including those of a historical nature. The second principle is the non-coercion principle. In the words of the Committee:

\footnotetext{
${ }^{4}$ Antoon De Baets, "Democracy and Historical Writing," Historiografías / Historiographies no. 9 (June 2015): 31-43, https://unizar.es/historiografias/numeros/9/debaets.pdf ${ }^{5}$ HRC, General Comment 34, §9.
} 
Any form of effort to coerce the holding or not holding of any opinion is prohibited. ${ }^{6}$

Coercion is inconsistent with the freedom to hold opinions. In other words,

from a human rights perspective, historians are not obliged to adopt the interpretations of past events or the moral judgments about the conduct of historical figures made by others; and citizens in general are not obliged to comply with a duty to remember imposed on them by others. ${ }^{7}$

\section{Article 19.2: The Expression of Opinions}

Whereas article 19.1 focuses on the individual as such, article 19.2 focuses on the individual in a social context. It establishes the right to freedom of information and expression. This is a right of persons looking for information and ideas ("seek"), persons expressing opinions ("impart"), and the public interested in hearing them ("receive"). Here, a third principle emerges, the right to err. According to the Committee:

The Covenant does not permit general prohibition of expressions of an erroneous opinion or an incorrect interpretation of past events. ${ }^{8}$

\footnotetext{
${ }^{6} \mathrm{HRC}$, General Comment 34, $\$ 10$. The quote continues: "Freedom to express one's opinion necessarily includes freedom not to express one's opinion." See also article 18.2 ICCPR; HRC, General Comment 22 [on freedom of thought] (1993), §5.

${ }^{7}$ See for a full discussion, Antoon De Baets, Responsible History (New York and Oxford: Berghahn, 2009), chapter 5 ("The Rights to Memory and History"). The non-coercion principle is also stated in article 18.2 ICCPR.

${ }^{8}$ HRC, General Comment 34, §49. This right to err echoes the views of John Stuart Mill, who in 1859 argued that erroneous and false opinions are valuable because they challenge disbelievers to refute them in order to come closer to the truth. In the process, some of the supposedly erroneous or false information could turn out to be true after all. John Stuart Mill, On Liberty (London: Parker \& Sons, 1859), chapter 2.
} 
This right to err refers to opinions and less so to facts. Statements of fact are indeed distinguished from statements of opinion. From a human rights perspective, historical facts are susceptible to a truth/falsity proof while historical opinions are not. This distinction between facts and opinions is an important fundament of legal epistemology. It means that expressing opinions enjoys a far stronger protection than expressing statements of fact.

\section{Article 19.3: The Restriction of Opinions}

Article 19.3 embodies the idea that the right to freedom of expression, although universal, is not absolute. It describes the standards to permissibly restrict free expression. ${ }^{9}$ Four general principles underlie these standards. First, restricting a right in order to protect it is delicate and, therefore, the scope of restrictions on free expression is itself restricted and should never undermine the essence of the right. ${ }^{10}$ Second, only states may permissibly restrict free expression. Third, the exercise of the free expression right carries with it special duties and responsibilities. This clause is first and foremost applicable to the state. States have responsibilities to respect (that is, not interfering with the free expression when it is not necessary), to

\footnotetext{
${ }^{9}$ See for the restriction principles, in particular, United Nations (UN) Economic and Social Council, Siracusa Principles on the Limitation and Derogation Provisions in the International Covenant on Civil and Political Rights (1985), part I, and Report of the Special Rapporteur on the Promotion and Protection of the Right to Freedom of Opinion and Expression (A/HRC/14/23; 2010), §§72-87, especially §79. See also Toby Mendel, Restricting Freedom of Expression: Standards and Principles (Halifax: Centre for Law and Democracy, 2011) and "Themes and Issues," in Information, Freedom and Censorship: World Report 1991, edited by Article 19 (London: Library Association Publishing, 1991), 409-440, for discussion.

${ }^{10}$ See also article 5 ICCPR.
} 
protect (that is, preventing private actors from interfering with the free expression of others) and to fulfill (that is, facilitating free expression by means of legal, financial, promotional and other measures) $\cdot{ }^{11}$ Historians, in their turn, have also duties that come with the exercise of the right to free expression - for example, the duty not to express discriminatory views when they act as symbols of authority in a teaching context. ${ }^{12}$ Fourth, the standards are applicable at all times, including times of public emergency, although states may then take temporary measures derogating from their responsibilities under strict conditions. ${ }^{13}$

\section{The Three-Part Test}

Based on these principles, a sophisticated method to assess the appropriateness of restrictions on free expression was developed. It is internationally accepted and best known as "the three-part test." ${ }^{14}$ The first branch of the test prescribes that the restriction should be "provided by law." In order to understand this branch of the test, we should first have a grasp of the rule of law. According to the United Nations:

\footnotetext{
${ }^{11}$ See also article 2.2 ICCPR.

${ }^{12}$ See HRC, Ross v Canada (736/1997) (2000), §11.6: "[T] he Committee recalls that the exercise of ... freedom of expression carries with it special duties and responsibilities. These ... are of particular relevance within the school system, especially with regard to the teaching of young students ... [T] he influence exerted by school teachers may justify restraints in order to ensure that legitimacy is not given by the school system to the expression of views which are discriminatory." See also European Court of Human Rights (ECHR), Gollnisch v France (48135/08) (2011), 12, 14. ${ }^{13}$ See article 4.1 ICCPR and Siracusa Principles, part II.

${ }^{14}$ Also called "triple test" or "justification test."
} 
The "rule of law" ... refers to a principle of governance in which all persons, institutions and entities, public and private, including the State itself, are accountable to laws that are publicly promulgated, equally enforced and independently adjudicated, and which are consistent with international human rights norms and standards. It requires, as well, measures to ensure adherence to the principles of supremacy of law, equality before the law, accountability to the law, fairness in the application of the law, separation of powers, participation in decision-making, legal certainty, avoidance of arbitrariness and procedural and legal transparency. ${ }^{15}$

A focal part of the rule of law is legality. The central idea of the legality principle is that restrictions on free expression cannot be imposed by the whims of a public official on the spot; they should be enshrined in preexisting laws which are consistent with international human rights standards. Furthermore, laws imposing restrictions must be publicly accessible (they cannot be secret), and described in clear, precise and unambiguous language, so that everyone can understand them. They should also be equally enforced. Laws containing vague and overbroad formulations expand the range of persons permitted to implement them, give them too much power, create uncertainty and arbitrariness and produce a chilling effect (a deterring effect) on free expression. ${ }^{16}$ In its General Comment 34, the ${ }^{15}$ UN Secretary-General, The Rule of Law and Transitional Justice in Conflict and Post-
Conflict Societies (S/2004/616) (2004), $\$ 6$. See also http://un.org/en/ruleoflaw and
data.worldjusticeproject.org. The definition of rule of law is inspired by, among others,
article 8 of the Déclaration des droits de l'homme et du citoyen (1789) and Lon Fuller's
classic The Morality of Law (New Haven and London: Yale University Press, 1964), 33-94,
discussing eight requirements for legality: generality; promulgation; non-retroactivity;
clarity; non-contradiction; capability of being obeyed; constancy through time; congruence
between law declared and law administered. About unjust laws, read Franz Kafka, The Trial
(originally in German, 1925).
${ }^{16}$ Article 15 ICCPR emphasizes one element of the legality principle: the prohibition of
retroactive application of criminal laws (nullum crimen sine lege). No one may be convicted
for an act or an omission that did not constitute a criminal offence under national law (both
statutory and common-law norms) or international law (both treaty and customary law) at 
Human Rights Committee expressed concern over several law types that may threaten free expression, including national security laws, memory laws, blasphemy laws, hate speech laws and genocide denial laws and many others.

It is also well-known that most dictatorships invest much energy in keeping up a semblance of legality in a contorted attempt to enhance their legitimacy. ${ }^{17}$ Often, they function under a martial law regime. But dictatorial decrees do not meet the legality principle. Some blatantly prescribe an entire ideology, others facilitate the persecution of dissidents or the ban on their publications under the guise of national security or anti-terrorism laws. Still others are secret laws, laws with secret interpretations or laws with overbroad secrecy regulations or blanket amnesties granting immunity for perpetrators of human rights violations. These unjust laws, or their remnants, sometimes survive in democracies.

The second branch of the test enumerates a list of legitimate interests (or aims) on which free expression restrictions can be based. These interests can be private (the respect of the rights or reputations of others) or public (the protection of national security, of public order, of public health and of public morals). Among the private interests, reputation is straightforward,

the time it was committed. This means that a person may be prosecuted if accused of acts that were criminal under international law when they were committed, even if these were not defined as criminal under national law at the time. The latter is emphasized in article 15.2 ICCPR, according to which prosecution is possible "for any act or omission which, at the time when it was committed, was criminal according to the general principles of law recognized by the community of nations [italics $a d b] . "$

${ }_{17}$ See, for example, Robert Conquest, The Great Terror: A Reassessment (New York: Oxford University Press, 1990), 130-131. 
but the catch-all expression "rights of others" is less clear. In various legal cases, it has been understood to include, among others, the rights to copyright, to privacy and to equality. The phrase has also been invoked to protect the honor and dignity of genocide victims (deceased and surviving) and their relatives and descendants. ${ }^{18}$ The "rights of others" relate to both individuals and the community as a whole.

The public interests mentioned in article 19.3 ICCPR are generally recognized as legitimate for the survival and functioning of society and the state (the latter as the legal and political manifestation of society). National security should be understood as the protection of:

[T] he existence of the nation or its territorial integrity or political independence against force or threat of force. ${ }^{19}$

This includes the possibility to shield sensitive information from the public. Public order should ideally be:

[T] he sum of rules which ensure the functioning of society or the set of fundamental principles on which society is founded. Respect for human rights is part of public order. ${ }^{20}$

The interest of public health (the third public interest) does not play a major role in the study of the past. In contrast, the interest of public morals certainly does. The Siracusa Principles that clarify the concept stipulate:

Since public morality varies over time and from one culture to another, a state which invokes public morality as a ground for

\footnotetext{
${ }^{18}$ See ECHR, Perinçek v Switzerland (27510/08) (2015), §§143-144, 155-157.

${ }^{19}$ Siracusa Principles, §29.

${ }^{20}$ Siracusa Principles, §22; see also ECHR, Perinçek, §§146-154.
} 
restricting human rights, while enjoying a certain margin of discretion, shall demonstrate that the limitation in question is essential to the maintenance of respect for fundamental values of the community. The margin of discretion left to states does not apply to the rule of non-discrimination as defined in the Covenant [the ICCPR, $a d b] .{ }^{21}$

Expressing the same non-discrimination idea, the Human Rights Committee

itself observed that:

[T] he concept of morals derives from many social, philosophical and religious traditions; consequently, limitations ... for the purpose of protecting morals must be based on principles not deriving exclusively from a single tradition. ${ }^{22}$

Significantly, the list of private and public interests is exclusive. Other interests than the ones listed in article 19.3 are not permissible as restriction grounds. As the Human Rights Committee tells us:

[I]t is not compatible with the Covenant for a restriction to be enshrined in traditional, religious or other such customary law. ${ }^{23}$

This means that free expression restrictions in the name of "tradition," "custom," "culture," or in the name of "national pride," "protection of memory" or "insult to the fatherland" should all be discarded as invalid. ${ }^{24}$

\footnotetext{
${ }^{21}$ Siracusa Principles, $\S \S 27-28$.

${ }^{22}$ HRC, General Comment 22, §8 and General Comment 34, §32.

${ }^{23} \mathrm{HRC}$, General Comment 34, §24, also §32. See also Joint Declaration on Universality and the Right to Freedom of Expression (2014), §§1b, $1 \mathrm{f}$.

${ }^{24}$ For the protection of tradition, see Graeme Reid, "The Trouble with Tradition: When 'Values' Trample Over Rights," in World Report 2013, edited by Human Rights Watch (Washington: Human Rights Watch, 2013), 20-28. For the protection of memory, see Article 19, Memorandum on the Russian Draft Federal Law "On Combating the Rehabilitation of Nazism, Nazi Criminals or their Collaborators in the Newly Independent States Created on the Territory of Former Union of Soviet Socialist Republics" (London: Article 19, 2009), 13.
} 
The third branch of the test prescribes that restrictions should be "necessary" to achieve the protection of the interests. The necessity principle stipulates that the restriction must address a pressing social need. ${ }^{25}$ The proportionality principle, a part of the necessity principle, defines two other conditions: the benefit flowing from the restriction must outweigh the harm it does to free expression and the restriction which was selected should be the least intrusive measure available. Restrictions that are "unnecessary" or "disproportional" (for example, harsh sanctions) produce chilling effects that may unduly restrict free expression of the person concerned and others. ${ }^{26}$

The three-part test has stood the test of time. If states fail the test, a violation of the right to free expression has occurred.

\section{Article 20: The Prohibition of Opinions}

Article 20 of ICCPR is an extension of article 19.3. Whereas article 19.3 is about restricting opinions, article 20 is about prohibiting them. Strictly speaking, the acts prohibited under article 20 are not even considered as opinions. In the words of the Human Rights Committee:

[F]or the acts addressed in article 20, the Covenant indicates the specific response required from the State: their prohibition by law. It is only to this extent that article 20 may be considered as lex specialis with regard to article $19 .{ }^{27}$

\footnotetext{
${ }^{25}$ In Europe, the usual formula is "necessary in a democratic society."

${ }^{26}$ See also HRC, General Comment 34, §§34-35.

27 HRC, General Comment 34, §51.
} 
This means that governments have a duty to enact laws prohibiting war propaganda (article 20.1 ICCPR) and laws prohibiting "any advocacy of national, racial or religious hatred that constitutes incitement to discrimination, hostility or violence" (or hate speech for short) (article 20.2 ICCPR).

\section{Epilogue}

This is, in a nutshell, the international free expression framework insofar as it is relevant for the problems of historians. The framework is a coherent whole of fundamental principles, all of which have to be carefully balanced against one another. It can be used to discuss those laws that directly aim at restricting what historians say or write about the past and to test arguments about the role of history and archives in discussions about free expression, information and secrecy.

\section{References}

Article 19. Information, Freedom and Censorship: World Report 1991. London: Library Association Publishing, 1991.

. Memorandum on the Russian Draft Federal Law "On Combating the Rehabilitation of Nazism, Nazi Criminals or their Collaborators in the Newly Independent States Created on the Territory of Former Union of Soviet Socialist Republics." London: Article 19, 2009. Accessed June 19, 2016. https://www.article19.org/resources.php/resource/1257/en/russia:memorandum-on-the-draft-federal-law- 
Conquest, Robert. The Great Terror: A Reassessment. New York: Oxford University Press, 1990.

De Baets, Antoon. "Democracy and Historical Writing." Historiografías / Historiographies no. 9 (June 2015): 31-43. Accessed June 19, 2016. http://www.unizar.es/historiografias/numeros/9/debaets.pdf

2009.

. Responsible History. New York and Oxford: Berghahn,

European Court of Human Rights. Bruno Gollnisch v France (48135/08), 2011. Accessed June 19, 2016. http://hudoc.echr.coe.int/eng?i=001105440

. Perinçek v Switzerland (27510/08), 2015. Accessed June 19, 2016. http://hudoc.echr.coe.int/eng?i=001-158235

Fuller, Lon. The Morality of Law. New Haven and London: Yale University Press, 1964.

Kafka, Franz. The Trial. London: Secker and Warburg, 1947(originally German, 1925).

Mendel, Toby. 2011. Restricting Freedom of Expression: Standards and Principles. Halifax: Centre for Law and Democracy. Accessed Sepetmber 29, 2016. http://www.law-democracy.org/live/wpcontent/uploads/2012/08/Paper-on-Restrictions.10.03.22.rev_.pdf

Mill, John Stuart. On Liberty. London: Parker \& Sons, 1859.

National Assembly of France. Declaration of the Rights of Man (Déclaration des Droits de l'Homme et du Citoyen. 1789. Accessed June 19, 2016. http://avalon.law.yale.edu/18th_century/rightsof.asp

Reid, Graeme. 2013. "The Trouble With Tradition: When 'Values' Trample Over Rights," in World Report 2013, edited by Human Rights Watch, 20-28. Washington: Human Rights Watch. Accessed June 19, 2016. https://www.hrw.org/world-report/2013 
United Nations. United Nations and the Rule of Law. Accessed June 19, 2016. http://un.org/en/ruleoflaw

United Nations Economic and Social Council. Siracusa Principles on the Limitation and Derogation Provisions in the International Covenant on Civil and Political Rights. E/CN.4/1985/4, Annex. 1985. Accessed June 19, 2016. http://hrlibrary.umn.edu//instree/siracusaprinciples.html

United Nations Office of the High Commissioner for Human Rights. General Comment 10 on Freedom of Expression. June 29, 1983. Accessed June 19, 2016. http://www.ohchr.org/Documents/Issues/Opinion/CCPRGeneralComme ntNo10.pdf

. General Comment 11 on Prohibition of Propaganda for War and Inciting National, Racial or Religious Hatred. July 29, 1983. Accessed June 19, 2016. http://www.ohchr.org/Documents/Issues/Opinion/CCPRGeneralComme ntNo11.pdf

. General Comment 22 on Freedom of Thought, Article 18. 1993. Accessed June 19, 2016. http://hrlibrary.umn.edu/gencomm/hrcom22.htm

. General Comment 34 on the Freedoms of Opinion and Expression. September 12, 2011. Accessed June 19, 2016. http://www2.ohchr.org/english/bodies/hrc/docs/gc34.pdf

. International Covenant on Civil and Political Rights.

December 16, 1966. Accessed June 19, 2016. http://ohchr.org/en/professionalinterest/pages/ccpr.aspx

. Malcom Ross v. Canada. Communication No. 736/1997, U.N. Doc. CCPR/C/70/D/736/1997 (2000). Accessed June 19, 2016. http://hrlibrary.umn.edu//undocs/736-1997.html

- Ratification, International Covenant on Civil and Political Rights. Accessed June 19, 2016. http://indicators.ohchr.org 
. Report of the Special Rapporteur on the Promotion and

Protection of the Right to Freedom of Opinion and Expression.

A/HRC/14/23, April 20, 2010. Accessed June 19, 2016.

http://www2.ohchr.org/english/bodies/hrcouncil/docs/14session/A.HRC.

14.23.pdf

United Nations Security Council. The Rule of Law and Transitional Justice in Conflict and Post-Conflict Societies. S/2004/616, 2004. Accessed June 19, 2016. http://www.ipu.org/splz-e/unga07/law.pdf

United Nations Special Rapporteur on Freedom of Opinion and Expression,Organization for Security and Co-operation in Europe Representative on Freedom of the Media, Organization of American States Special Rapporteur on Freedom of Expression, and African Commission on Human and Peoples' Rights Special Rapporteur on Freedom of Expression and Access to Information. Joint Declaration on Universality and the Right to Freedom of Expression. May 6, 2014. Accessed June 19, 2016. http://www.osce.org/fom/118298

World Justice Project. Rule of Law Index. Accessed June 19, 2016. http://data.worldjusticeproject.org

\section{Biographical note}

Antoon De Baets (Ph.D. 1988) is professor of History, Ethics and Human Rights by Special Appointment of the Foundation EUROCLIO at the University of Groningen, the Netherlands. He wrote 175 publications, mainly on the censorship of history and the ethics of historians. His work includes several books, the latest of which in English is Responsible History (New York and Oxford: Berghahn Books, 2009). Since 1995, he has coordinated the Network of Concerned Historians. Furthermore, he is working on such issues as the relationship between historical writing and democracy; historians and archivists killed for political reasons; the subversive power of historical parallels; post-conflict history textbooks moratoria; posthumous privacy and reputation; intergenerational awareness; iconoclastic breaks with the past; academic freedom; history-related complaints before the United Nations; the legal framework of historical writing; and a theory of free expression about the past. 